\title{
Presumptions of Decentralisation in the Context of Institutional and Political Economy
}

\begin{abstract}
The aim of the article is to discuss and distinguish the notion of decentralisation within time, institutional economics and political organisation of States, as well as the role of decentralisation in the context of those political organisations. The differences between the notions of decentralisation and federalism are differentiated in order to avoid misinterpretations of the notions.
\end{abstract}

Keywords: decentralisation, institutionalisation, federalism, unitary regime.

Straipsnio tikslas - aptarti ir atskirti decentralizacijos sąvokų prasmès kitimą laike, institucinės ekonomikos ir politinès valstybių santvarkos kontekste. Straipsnyje analizuojami skirtumai tarp decentralizacijos ir federalizamo sąvokų bei jų reikšmių, siekiant išvengti neteisingo sąvokų interpretavimo ir supratimo.

Raktiniai žodžiai: decentralizacija, institucionalizacija, federalizmas, unitarinis režimas.

\section{Introduction}

There is no doubt in contemporary literature on politics and economics that decentralisation helps ensuring the efficiency, transparency of public governance, the participation of citizens in governance and the responsibility of local government to citizens. Keeping in mind relatively large quantity of literature on decentralisation, most often, when the attention is focused on reforms themselves, fiscal decentralisation, intergovernmental fiscal relationships, no attention in given to the context, thus the notion is not always used adequately. It is important to define whether the notions of decentralisation are equally clear, understandable and are interpreted in the same way in the histori- cal, social, political and economic context. If it is not so, the practical and scientific discussions might lead to different interpretations, hence different conclusions and outcomes.

The analysis in the article is needed to discuss multi-faceted aspects of decentralisation in assessing the complexity and many meanings of this phenomenon during different periods in countries having different economics and politics. The notion of decentralisation is often used without assessing its different aspects in individual dimensions. When the notion is made equal, its meaning is often distorted. Whereas listed or applied advantages and disadvantages do not reflect the actual situation. Therefore, in order to assess the level of decentralisation (irrespectively if it 
is political, economic or fiscal) in a country, first we have to understand its politi$\mathrm{cal} /$ institutional nature. Hence, the main aim of the article is to look at the notion of decentralisation in the context of its development, with regard to institutional aspect and making distinction between decentralisation and federalism. Only having clearly defined the notion of decentralisation in the context of institutional and political economy, we will be able to apply its presumptions, use its advantages and search for ways to compensate disadvantages because inadequate conceptualisation, which ignores a specific context of the country or mandatory application of processes prevent the optimum practical realisation of decentralisation.

The article discusses the change of the notion of decentralisation within time, institutional economics and political organisation of States, as well as the role of decentralisation in the context of those political organisations; analyses differences between unitary and federal States by stressing in parallel the differences between the notions of decentralisation and federalism, as well as their meaning and also the governance of processes themselves.

\section{Changes in meanings of the notion of decentralisation within time}

Before analysing multiple meanings of the current notion of decentralisation caused by different political and economic concepts, firstly a short review of the change of the notion of decentralisation within time will be presented.

Before 1970, decentralisation usually was understood in a narrow sense as the distribution of central government functions to lower governance levels as representatives of government. Thus, the notion of decentralisation corresponded more to the appointment of deputies for the same functions only by dispersing them geographically as the political power remained in the hands of the central government.

Since 1970, earlier reforms of decentralisation began, and they were implemented in order to achieve higher efficiency. Hence, the meaning of reforms of decentralisation from simple performance of functions in lower governance levels turned into the presumption of decreasing of inefficiency of central government (World Bank, 1990; Cheema, Rondinelli, 2007).

1980 was the year when the decentralisation of hierarchical government structures and bureaucratic government apparatus began diminishing the powers of central government in general in order to make government bodies more responsible and effective. During this period, decentralisation promoted the development of city government, demolition of bureaucratic systems, central governance planning and fragmentation of government to lower governance levels (Smoke, 2003). During this period, the concept of decentralisation expanded and included not only distribution of functions, but also of political power between governance levels, democratisation, liberalisation of market, and the deconcentration of political power was understood as the presumption of economic efficiency and social improvement.

Since 1990, citizen becomes the centre of attention and the notion of decentralisation already means concentrating 
of provision of government services closer to the citizen and their needs. The notion of decentralisation is completed by concepts of local government accountability, responsibility with regard to local citizen, and the activities of institutions are directed towards the improvement of wellbeing of local residents. This argument is based on the point of view that the local government may be more accountable to citizens than the central government (Seabright, 1996; Persson and Tabellini, 2000). Another important aspect of public finances or public economics that emerged in that period is political debate concerning the participation of the State in the economics in considering how much public sector has to participate in the economy in maintaining the balance between the wellbeing of the State and the efficiency of the free market; what roles the public sector should have in the State and in what level of governance and what roles the private sector should have; also how important is the role of the society in the policy-making.

According to European Charter of Self-Government (1985), self-governance institutions form the grounds of every democratic organisation. The fundamental principle of democracy is the right of the citizens to participate in governance of public affairs. In the most effective way, it can be implemented through local government institutions.

These principles correspond to the current trends in Western democratic countries. The development of democratic principles in European counties results in decentralisation processes in public governance field, by attributing increasingly growing share of governance of public affairs to local self-governance institutions, thus also increasing their importance in governance of the State. Local self-governance means that without crossing the limit established by the laws, local government bodies have the right and the ability to manage and govern a respective part of public affairs by taking care of interests of local residents and assuming full responsibility. Local government bodies have the right to implement powers granted by central or regional government bodies at their own discretion and with regard to local conditions.

Hence, we come to the notion of institutional economics and role of institutions in decentralisation process and creation of citizens' wellbeing. More attention is given to forms of construction of democratic society in local self-governance by including citizens to local self-governance processes. The notion of decentralisation is less often used as a general one, but according to the meaning, it was started to divide it into three notions: devolution, deconcentration and delegation.

The centre of attention of institutional economics (institutionalism) is the understanding of the role of evolution process and effect of institutions on economic behaviour. The key idea is derived from Thorstein Veblen's instinctive dichotomy between technologies, of the one part, and "ceremonies" of the society, of the other part (Dorfman, 1934; Brette, 2003). The term of institutional economy and its initial elements are found in the article of Walton Hamilton published back in 1919 (Hamilton, 1919). In general, institutional economics analyses how society's institutions cause economic processes. As decentralisation is not distinguished from activities of local self-governance institutions and their 
participation in socioeconomic context, it is important to understand the integration of institutions with new functions both to processes of local self-governance and in the overall economic context of the country. Institutional economics stresses the importance of broader analysis of institutions and assesses markets as a result of complex interinstitutional (individuals, companies, State, local government institutions, social standards) interaction.

As mentioned above, since 1990, decentralisation is identified as a measure for improvement of efficiency of public services, also as a more transparent and more responsible form of governance (Ribot, 2004). When decentralising powers of government, it is aimed for more productive adoption of decisions by local government institutions that is necessary in order to ensure democracy and good governance practice (Osei-Kufuor and Bakare, 2013). Hence, the role of institutions acquires a new meaning, and therefore it is relevant to review the essence of institutional economics.

The principle object of interinstitutional research is organisation and control of economy, rather than marketing and distribution of resources. According to institutionalists, the economics cannot be limited just by the market because the operating mechanism of distribution of resources does not meet the abstract notion of market; in order to use it, it is necessary to look into particular institutions, their functionality, structure of central and local government because that in particular creates market and operates through it. In trying to reveal defects of orthodox theory, representatives of modern institutionalism bring out new theories, propose other methods of understanding of economic phenomena and processes. Institutionalists pay a lot of attention to the explanation of economic and political motives of an individual's behaviour. It is proposed to see an individual not as a separate subject, but as a part of the social system.

Institutionalism is the theory of social control and changes, where a lot of attention is given to property, corporations, State, intergovernmental institutions. The principle statement of institutionalist microeconomics is the following: distribution of resources is a function of government structure, rather than the one of the market. The government and its institutions create the market and operate through it, distribute income and cash flows. Institutional macroeconomics results from institutionalist microeconomics that is similar to the developing postkeinsism macroeconomics (Frank, 1986).

Economic indicators of the latter, such as level of income, amount of issued production, employment and level of prices are the function of the government. Institutionalists stress the fact that the mechanism of prices does not operate in accordance with the neowalrasian model. Institutionalists distinguish the oligopolistic core and competition periphery that make up marketing.

Following Wesley Mitchell, one of their pioneers, institutionalists stress the financial and especially monetary nature of economics. They stress the dependence of macro-economic indicators both on variables that define the behaviour of people and on structure of the government. According to them, the State makes up an important part of economic system, without it the economic system would not 
be what it is today. Institutionalists recognise that the State is the most important measure of implementation of the society's collective actions and therefore must be analysed in investigating processes of social control and social changes. According to institutionalists, the State and the law are two inextricably linked notions. Economics is an object of legal control and the State is the measure of receiving of economic benefit. The economics itself is the result of the State and its politics. According to institutionalists, State and economic organisations are each other's result.

Institutionalists criticise mechanical positivism of neoclassical orthodoxy, its chosen method of human nature designing. They claim that neo-classicists do not understand the problem of government, they simply cannot see it. When creating theories and performing research, institutionalists themselves always try to be realists (Martišius, 2005).

Hence, institutional and political organisations of States also cause economic assessments of phenomena of those States. The role of institutions and government remains especially relevant in decentralisation processes because the interinstitutional coordination of actions and politics determine, whether the result of decentralisation, as a measure of improvement of efficiency of governance activities, will be attained.

However, the role of institutions, for its part, depends on the organisation of States. The notion of decentralisation is often mixed with the notion of federalism. Therefore, below we are going to analyse political organisations of States and the notions of decentralisation or federalism caused by them.

\section{Decentralisation and Federalism}

Traditionally States are divided into unitary and federal, depending on organisation of political system. The governance system of the first ones includes two governance levels: central and local, and the system of the second ones is completed with more governance levels. However, many historically unitary States carry out reforms, by means of which they intend to move towards a more decentralised governance. Such countries cannot be called purely federal systems, but at the same time they are no longer representatives of purely unitary governance (Figure 1) because lower governance levels are entrusted with increasingly higher amount of responsibility, which previously was held by the central government (Bosh, Duran, 2008).

$\begin{array}{ccccc}\text { Centralised } & \text { Decentralised } & \text { Federal } & \text { Confederal } & \text { Anarchy } \\ \text { unitary } & \text { unitary } & \text { systems } & \text { systems } & \\ \text { systems } & \text { systems } & & \end{array}$


However, modern discussions should not be limited to only two forms of governance of States: unitary or federal State. More analysis should be conducted on what is the structure of the country's governance with regard to the levels of government, what rights and obligations are attributed to particular levels of governance. Therefore, when conducting more in-depth analysis, the four systems of countries' governance may be distinguished in accordance with distribution of intergovernmental functions, power and finances:

- Centralised unitary States;

- Decentralised unitary States;

- Federal States;

- Confederal States.

Centralised unitary States mean such a system of governance, where the entire governance of the State is concentrated in the hands of the central government. In such a system, only central government has the legislative, enforcement and penalty powers. It has centralised administrative control, centralised budget and centralised planning system. Decentralisation, if any, depends on the power of the central government and most often manifests itself by delegation or deconcentration.

Decentralised unitary States. Despite the fact that unitary State principles are applied in this system, civil government is recognised by granting powers, functions and right to local government institutions that are closer to citizens and understand their local needs better. According to U. Cloety, transferring of governance is related with dual federalism. In such a system, works, obligations and rights are divided constitutionally between the chosen local government units and the higher government. This system includes local government institutions directly elected by local citizens and responsible to local citizens for their activities and performed functions (ADDCN, 2007). In decentralised unitary States, local government operates in performing its obligations, issues legislation, develops policies and programmes, adopts administrative and political decisions, mobilises and manages financial resources (by determining and collecting taxes), organises administrative activities and manages its human resources as autonomously as defined in the Constitution and national legislation.

Importance in this system is given to intergovernmental agreements that ensure that local government institutions, communities of citizens can freely use their rights and properly perform all functions of a respective governance level following the principle of subsidiarity. It is a participation system based on local democracy, where central government assumes responsibility and obligations of national level, to perform which the local government has no possibilities. It is usually accepted that all State functions may be performed by units of autonomous government, except for development and implementation of monetary policies, foreign policies, international relations, function of State guard, as well as the national court system because the abovementioned functions belong to the responsibility of the central government. Denmark, Sweden, Norway are the best examples of this system.

It is necessary to assess that the motivation encouraging the process of decentralisation is different in various States. R. Bird and R. Ebel (2007) present a series of works on fiscal fragmentation, by firstly 
posing two fundamental questions: "What is decentralisation?" and "Why does decentralisation occur?". Concerning the same question, R. Ebel and S. Yilmaz (2002) claim that developed countries carry out processes of decentralisation in order to avoid ineffective government, macroeconomic instability and inadequate economic growth, while the decentralisation of post-communist States' public sector accompanies the movement towards the market economy and democracy (Dafflon, Madies, 2009).

Federal organisation occurs in two ways. The first one: different independent States agree to create a federal State or confederation (such as USA and Switzerland); the second: when centralised government is transformed into a federation by creating regional autonomous States in order to defend racial, linguistic or cultural peculiarities and to decentralise the governance into the lower level of government. In accordance with their nature, federal systems may be divided into two groups: federal States and confederal States.

Federal States theoretically are described as systems of State, where local level government institutions have rights guaranteed by the Constitution and have no need to depend on the central government. In this system, the federation is formed not by independent States or nations, but the integrated States themselves decide on the constitutional grounds for forming of the federation, on nature and form of rights granted to States or provinces (e.g., India, Australia and South Africa have this system).

Confederate States operate in accordance with the system, where autonomous administrative/territorial units give the authority to the central government. A prior condition for operation of this system is the will of autonomous units to have certain responsibility and rights, as well as their intention to transfer certain responsibility and rights to the central government and in this way form the confederation, where the agreement to unify under certain conditions is made. In the federation, central authority and several (dozens or several dozens) States or otherwise called administrative units that have more powers and autonomy than the central authority are formed.

Despite the fact that the features of federal organisation may be met by more than one state, the grounds of their development or operation principles may differ. Different countries have made federations on different grounds and motives: geographic, topographic, racial, and linguistic or for distribution of natural resources. For example, in Switzerland, the confederation contract of 25 independent cantons was signed in 1848 due to political motives, when autonomous administrative units under the pressure of neighbouring European countries that were becoming stronger, decided to conclude a contract and create a federation with central authority that would have one of the initial functions of the State, that is national defence. In such a way, citizens of different languages and cultures have been existing for many years "under one roof" maintaining relatively high independence of local government. Hence, even now citizens of the Switzerland have maintained double loyalty: politically they are loyal to their country, but in terms of culture, they feel related with the closest neighbouring country (Fleiner, 2000). Whereas in India confederation was created on linguistic 
grounds, in Nigeria and Ethiopia it was created on racial grounds. In the federation of Germany one language is spoken, whereas in South Africa more than ten languages are spoken. Russia with its huge territory has adapted the federal system, as well as a small country Micronesia. The countries of this system have both monarch and parliament governance, and deep democracy (Switzerland), as well as military regime (Pakistan).

\section{Right of self-determination in the context of federalism}

Due to its specifics, the level of right and freedom of self-determination in the federal system is "inherited", but in the modern world no federal countries provide a complete right of self-determination to its federal units, i.e., there is no absolute federalism. Hence, the rights and freedoms of self-determination of administrative units of the federal system may be assessed only in a certain scale. Of course, the majority of expressions of federalism may be observed in the United States of America or the Switzerland, which in the first stage had the idea of absolute federalism.

Hence, only having described the political context of a country, i.e., to which system - unitary or federal - it belongs to, we can speak about the analysis of levels of decentralisation or federalism. In other words, if a country is considered as having unitary system, the level of decentralisation of local government, i.e., independence from central government is analysed, and when a country is considered as having federal system, the level of autonomy of federalism (federal administration units) is analysed.

\section{Local self-governance in unitary and federal systems}

In the majority of countries of the world, both unitary and federal, contemporary local government has the right of selfgovernance in various shapes, also a very varied level of local government's independence, freedoms and responsibility. After the 1990s, in the majority of countries of the world, institutional changes could have been felt in decentralisation of activities of local self-governance, altering constitutional provisions and legislation that granted the right to democratic and independent local self-governance and its development.

Traditionally, it is believed that local self-governance institutions of federal countries have more rights and freedoms than decentralised local self-governance units. However, it is not completely true assessment because lately in unitary States intensive processes of decentralisation are being carried out as well, during which local governance is granted with more and more rights and freedoms. Therefore, it is difficult to distinguish fundamental conceptual differences between the decentralisation of unitary States and the federalism of federal States. In order to assess the degree of decentralisation of a particular country it is particularly important, as mentioned before, to assess the context of institutional and political economy of a particular country.

When assessing in the general sense, it is hard to say which system, unitary or federal, may decentralise more powers to lower governance levels. It is also difficult to unambiguously answer the question, which system is more convenient for units 
of lower level self-governance in the context of rights and freedoms. Such a situation exists because in different countries there are no unified conditions of federalism and unified level of decentralisation. Today, in terms of autonomy and power, both federal and unitary States have more characteristics of both systems, rather than characteristics of a single system.

Hence, we see that between unitary and federal States there are not only differences, but also many similarities. Due to this reason and due to intensive increase of decentralisation process during the last decades, it is not as easy to describe the notion of decentralisation because its meaning depends on the majority of institutional agreements. Moreover, the field of the description between the decentralisation and fiscal federalism often overlap.

\section{Fiscal federalism or decentralisation?}

Before analysing fiscal federalism or decentralisation, it is necessary to discuss terminology in order to avoid ambiguity between these two terms. The most important thing that should be kept in mind is that these terms are neither synonyms, nor antonyms. Their mutual relationship may be explained from different points of view:

1) From the point of view of constitutional law. From this point of view, three organisations of State exist: (as mentioned above, recently four of them are distinguished because it was also started to divide unitary States into centralised and decentralised), unitary, federal and confederal, the features of which have already been discussed in detail above.

2) From economical point of view. As claimed by W. E. Oates, from the eco- nomical point of view, the majority, if not all systems, are federal (1972, p. 18). According to him, the difference between governance systems is measured by a degree, rather than a category. At one end of continuation of systems of States unitary regimes are placed, where all decisions are made by the central government, and at the other end is the anarchy State, where everyone does what they want (Figure 1). Between these two extremes, we can find more or less decentralised governance systems of all States of the world.

With regard to the fact that the logic of centralisation/decentralisation and unitary/federal State does not overlap, the governance systems of the States may be explained in two-dimensional space (Figure 2). This will allow imagining different compositions that differ centralised federal systems (such as Germany) and decentralised unitary systems (such as Spain).

It should be noted that the "unitary/ federal" dimension is presented in Figure 2 from the point of view of constitutional definition; it is the principle document defining the basic status of the country and establishing its place on the horizontal axis. Meanwhile the dimension of "centralisation/decentralisation" arises from the concept itself that is not so easy to define because, firstly, it depends on quantitative and qualitative assessment of governance functions and on lower governance levels. Therefore, it would be better to use not the general term "decentralisation", but assess the degree of deconcentration, delegation and devolution in each country.

Sometimes deconcentration is understood as unilateral decision of central government. In reality, there are two methods to consider decentralisation: in 


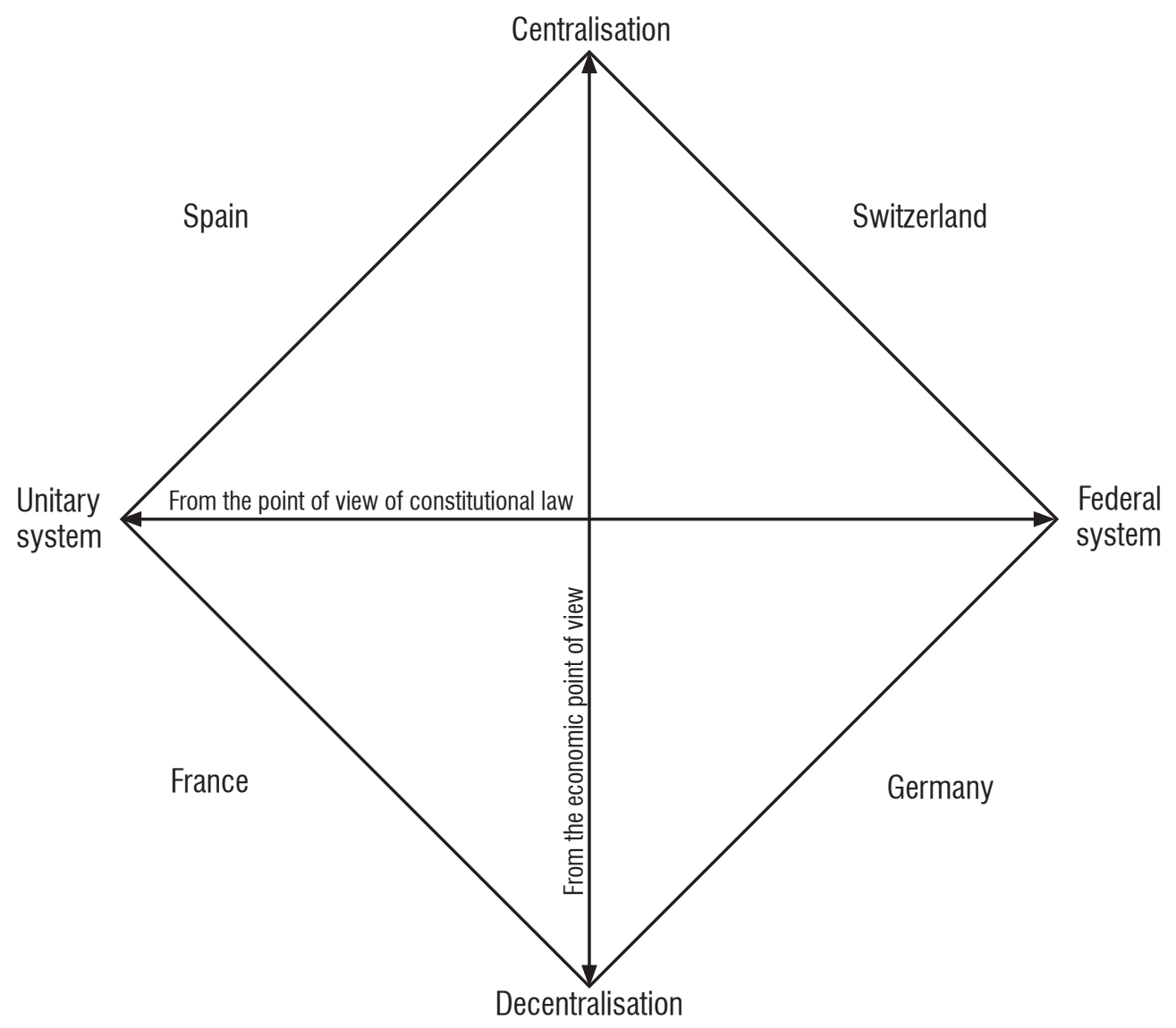

Fig. 2. Two-dimensional "map" of governance systems

Source: B. Dafflon and T. Madies (2009).

accordance with top down model or in accordance with bottom up model (Table 1). Objects of decentralisation and methods of implementation are different in each model.

In the first model of decentralisation, the central government has the power and strategic advantage to decide what functions, responsibility and financial resources are transferred to lower governance levels. This model is most often applied in unitary States and the process involves transfer of power and responsibility to specialised governance subjects (e.g., "functional" decentralisation) or to territorial governance subjects ("territorial" decentralisation). Such process may also be carried out in federal States, when central government shares the sovereignty of governance with other administrative units, but the latter ones do not dominate the central level.

The second model of decentralisation can be seen in practice less often: it is, in accordance with bottom up model, related with federal systems, where local administrative units have strong autonomy. 
Table 1. Two types of decentralisation

\begin{tabular}{|c|c|c|}
\hline & \multicolumn{2}{|c|}{ Types of (De)Centralisation } \\
\hline & Top down = to become local government & Bottom up $=$ to remain local government \\
\hline \multirow[t]{2}{*}{ Objectives } & $\begin{array}{l}\text { Transfer of fiscal limitations to the level } \\
\text { of local government (transfer of expenses } \\
\text { instead of transfer of governance) }\end{array}$ & $\begin{array}{l}\text { - To increase potential of local innovations } \\
\text { - To maintain variety of local public goods }\end{array}$ \\
\hline & \multicolumn{2}{|c|}{$\begin{array}{l}\text { - Creation of national wellbeing (better response of public goods demand/supply) maintaining } \\
\text { minimum possible standards of decentralised public politics } \\
\text { - Ensuring of good management practice, fiscal liability and accountability }\end{array}$} \\
\hline $\begin{array}{l}\text { Assessment } \\
\text { criteria }\end{array}$ & $\begin{array}{l}\text { - Cooperation in implementing objectives } \\
\text { established by central government }\end{array}$ & $\begin{array}{l}\text { Protectionism of local government and } \\
\text { maintenance of priority of local decisions }\end{array}$ \\
\hline $\begin{array}{l}\text { Forms and } \\
\text { methods }\end{array}$ & $\begin{array}{l}\text { - Deconcentration } \\
\text { - Delegation } \\
\text { - Devolution }\end{array}$ & $\begin{array}{l}\text { - Local autonomy } \\
\text { - Subsidiarity } \\
\text { - Decentralised cooperation } \\
\text { - Horizontal and vertical competition }\end{array}$ \\
\hline $\begin{array}{l}\text { Dominating } \\
\text { models }\end{array}$ & $\begin{array}{l}\text { - Vertical central and local government } \\
\text { relationships dominate } \\
\text { - Preferences of central government domi- } \\
\text { nate; model of chef/agent } \\
\text { - Information is in the hands of central } \\
\text { government }\end{array}$ & $\begin{array}{l}\text { - Conflict of central/local government (if } \\
\text { society is heterogeneous, decisions of local } \\
\text { government are different from decisions of } \\
\text { central government) } \\
\text { - Domination of local autonomy } \\
\text { - Subsidiarity } \\
\text { - Cooperation and competition } \\
\text { - Local (government) preferences dominate }\end{array}$ \\
\hline
\end{tabular}

Source: B. Dafflon and T. Madies (2009).

Table 2 also analyses the logic of decentralisation and fiscal federalism, but from the constitutional point of view of public finances. The table shall be "read" following the vertical axis of Figure 2 depending on the governance system. In the general sense, the economic analysis of the Constitution helps distinguishing two points of view:

1) In the case of "decentralised public finances", all powers and resources $a$ priori belong to the central government. The text of the Constitution shall clearly indicate the delegated and transferred powers or authorisations of collection of taxes that are submitted to lower level governance units. In such a way, the latter ones have the right to operate within the established limits (lower part of the vertical axes of Figure 2);
2) Yet pure form fiscal federalism attributes powers and resources to the local level de facto (upper part of the vertical axes of Figure 2). Constitutional procedure must be directed to the transfer of ones or others to a higher regional or central governance level.

Often, literature sources analyse decentralisation by in parallel calling it fiscal federalism and most often providing grounds for the example of experience of the USA. Such sources analyse principles that were successfully applied in decentralisation reforms in Argentina, Colombia, Brazil, South Africa, India and China (Bardhan, 2002). However, as seen from the above analysis, the phenomena are different and sometimes essentially. Therefore, in assessing the effect of reforms of decentralisation, it is necessary 
Table 2. Public finances according to governance form

\begin{tabular}{|c|c|c|}
\hline & Fiscal decentralisation & Fiscal federalism \\
\hline $\begin{array}{l}\text { Governance } \\
\text { system }\end{array}$ & $\begin{array}{ll}\text { - } & \text { Centralised federation (Germany) } \\
\text { - } & \text { Decentralised unitary (Spain) } \\
\text { - } & \text { Centralised unitary (France) }\end{array}$ & - Decentralised federal (Switzerland) \\
\hline $\begin{array}{l}\text { Constitutional } \\
\text { structure (of } \\
\text { an institution) }\end{array}$ & $\begin{array}{l}\text { - Activities of institutional organisations are } \\
\text { organised in accordance with normative } \\
\text { "structure" (number of governance levels, } \\
\text { territorial division, distribution of powers, } \\
\text { funding, transfer or resources) } \\
\text { - Constitution shall establish status of lo- } \\
\text { cal government and intergovernmental } \\
\text { relationships } \\
\text { - All powers that are not clearly attributed } \\
\text { to local government shall remain in the } \\
\text { hands of central government } \\
\text { - Preferences of central government are } \\
\text { dominating }\end{array}$ & $\begin{array}{l}\text { - Territorial distribution formed before } \\
\text { signing of the Constitution - ex post. } \\
\text { The Constitution ratifies powers of local } \\
\text { government } \\
\text { The Constitution is the reflection of } \\
\text { voluntary unification of sovereign local } \\
\text { government units; it also determines } \\
\text { intergovernmental relationships. } \\
\text { - In fact, government powers belong to } \\
\text { local and regional governments. Cantonal, } \\
\text { federal constitution clearly defines powers } \\
\text { transferred bottom up. The same shall also } \\
\text { apply to the transfer of financial resources, } \\
\text { except for grants (for the transfer of pow- } \\
\text { ers and resources double approval of the } \\
\text { majority (citizens and cantonal govern- } \\
\text { ment) is necessary }\end{array}$ \\
\hline $\begin{array}{l}\text { Model of } \\
\text { intergov- } \\
\text { ernmental } \\
\text { relationships }\end{array}$ & $\begin{array}{l}\text { - Typical models of "principle/agent" } \\
\text { - In centralised unitary States, principle } \\
\text { defines financial conditions and objectives } \\
\text { of performance of functions, as well as } \\
\text { the rules }\end{array}$ & $\begin{array}{l}\text { - Models of "negotiations between } \\
\text { principles" }\end{array}$ \\
\hline Typical cases & $\begin{array}{l}\text { Centralised federal countries (Venezuela, } \\
\text { Austria, India) } \\
\text { - Decentralised partially federal or unitary } \\
\text { countries (Spain, Holland, Sweden) } \\
\text { - Centralised unitary countries (France, } \\
\text { United Kingdom) } \\
\text {-Non-pure federalism" (Germany, USA) }\end{array}$ & $\begin{array}{l}\text { "dialogue/diplomacy" between provinces } \\
\text { and federal government in Canada } \\
\text { - Switzerland: cooperation principles } \\
\text { between the Confederation and cantons; } \\
\text { for coordination of functions of "canton } \\
\text { confederations"; consultation procedures; } \\
\text { initiative and referendum rights }\end{array}$ \\
\hline
\end{tabular}

Source: B. Dafflon and T. Madies (2009).

to clearly purify, what conception is discussed on political and economic levels. For example, decentralisation processes of post-soviet countries were influenced by completely different presumptions than the ones in the abovementioned countries. The economic/political and institutional contexts are in essence different, and the beginning of decentralisation reforms meant more physical deconcentration than the understanding of economic or social decentralisation effect.
As claimed by N. Devas (2008), arguments for decentralisation were divided into three principle and overlapping groups: administrative, political and economic. However, speaking of decentralisation and its advantages, it is important not to forget organisation of institutional economics and only after having assessed the latter, one can consider how much benefits provided by decentralisation can be empowered by the State. 


\section{Administrative arguments}

It is simply impossible to make all decisions on each area of the country from its centre. Central government lacks detailed knowledge on local needs and conditions. With regard to the fact that public services must be provided on local level, at least a part of decisions must be taken by local government institutions. It resembles the structure of a large organisation, when a part of decisions is transferred to local managers that better understand local needs and see local problems, as well as possible specific methods of their solving.

\section{Political arguments}

Democratic government means that citizens may choose how resources are used in their communities and how public services are provided. Local self-governance increases citizens' possibilities of participation and responsibility to electors, in this way developing democracy and increasing the soundness of democracy. It becomes clear in particular, where the population of countries is uneven in number, in a sense of racial, religious or geographical distribution, when needs and preferences are different in various regions. In essence, decentralisation increases the possibilities of participation and access to decision making to those groups that could not do that otherwise. In such a way the accountability and responsibility to citizens that have the possibility to be as close as they can to the first level of making of governance decisions and react in democratic ways and to express their political opinion is increased. It also gives the right to ethnical groups formed on the grounds of religion to en- sure the autonomy based on laws (Tanzi, 1996; Sonin, 2003).

Bosh and Duran (2008, ix) also stress that the principle question of good political decentralisation is to find a proper system of regional government funding. Regions must have adequate income for funding of public services provided by them in a way that they have the right to autonomy, but also assume responsibility for how that income is attracted. Hence, the objective is to reach autonomy by maintaining fiscal responsibility at the same time in parallel maintaining territorial solidarity, i.e. in order that richer and less rich districts would be furnished with the same level of public goods.

\section{Economic arguments}

It is claimed that decentralisation may improve the distribution of resources because decisions on resources better reflect local residents' needs, priorities and ability to pay (Tiebout, 1956; Qian and Roland, 1998; Maskin, Qian, and Xu, 1999). As a result, the provision of public services should also improve, and the citizens would prefer to pay for public services that are directly useful to them. According to C. Tiebout, in the local governance system, a user may, up to a certain level, check their residence in the community that provides "a fiscal package" that meets their priorities (Tiebout, 1956). On a theoretical level we can imagine a self-governance system, where, for example, each community uses different amount of public goods and where, as poetically stated by C. Tiebout, each user, who "votes with feet" may choose a community that meets their needs and priorities the best. However, unless it is one of 
the examples that support this "exit" model (i.e., when certain companies and rich residents left the New York city because the package of services and taxes for those services did not meet their needs), this theory has no completely real presumptions on possibilities of citizens to change their residence, as well as on information accessible to them, especially in developing countries. Therefore, in applying the presumptions of public choice theory to decentralisation reforms, firstly physical possibilities of citizens to "vote with feet" should be clearly assessed.

One of the most popular theoretical statements is that the needs of citizens related with the activities of public sector are better known and understood by local officials, rather than the ones representing the central government (Oates, 1972; Tanzi, 2000a, 2000b; Devas, 2008; Martinez-Vazques, 2008). Or, as claimed in the report from the World Bank (The World Bank, 1997, p. 120), powers of production of public products and services, as well as powers of supply should be transferred to lower governance level that is able to assume such a responsibility and coordinate expenses with the benefit.

Decentralisation process based on indicated arguments in the economics of the public sector acquires the form of fiscal decentralisation that reflects financial independence. Indeed, one of the most important functions of the State's public sector, the component part of which is municipalities, is the provision of public goods to the country's residents. Such activity also requires respective financial resources that are provided in the national budget.

Fiscal decentralisation is understood as division of financial independence of local government by delimiting functions of local and central governments in the public economy sector by respectively distributing financial resources in order to implement these functions. Economic ground for such decentralisation is the increase of the efficiency of public economics sector by decentralising economic functions of the public sector's economy.

Centralised supply of standard goods, irrespective of specifics of individual regions of the country and the variety of needs of the society's groups do not meet the needs of the society. Decentralisation of the public sector promotes economical effectiveness by creating more convenient conditions to supply such public goods that meet the needs of the users the most. Fiscal decentralisation in separate countries may be implemented on a narrower or broader level. In the first case, it is the transfer of financial powers to local institutions that may be fully or only partially subordinate to central government, however they are responsible to it. In the second case, decentralisation manifests itself by transfer of financial governance functions to self-governance institutions based on laws. Lately, by acquiring certain autonomy, self-governance institutions are becoming responsible not only to the government, but also to local electors, and that meets the local European selfgovernance principles better.

\section{Conclusions}

Typically, literature sources on the topic of decentralisation or fiscal federalism make the presumption that lower governance levels collect taxes and spend budget money. However, this aspect of collection and spending of money by local govern- 
ment does not show what powers and influence in particular the local government has on the administration of the aforementioned funds. In other words, what is the level of decentralisation in a particular State. In order to determine that level, decentralisation shall be analysed from different perspectives because it is a multifaceted phenomenon. There are countries that talk about decentralisation, when the local government only redistributes the taxes collected at the central governance level, however, there are countries, where local government is autonomous enough to govern its administrative units. Both cases concern decentralisation.

Hence, multi-faceted aspect of the notion must be clearly defined before analysing a particular situation in a particular country.

A very proper observation was provided by Jorge Martinez-Vazques (2008, p. 27-28) that decentralisation includes more than traditionally believed about matters of fiscal decentralisation (distribution of income, attribution of functions, distribution of expenses, system of transfer, etc.), and more than believed about political decentralisation (demo- cratically elected civil servants), or even more than believed about administrative decentralisation. All of it together is important aiming to assess the level of decentralisation or to attain it. The principle problem of some countries that have been implementing decentralisation reforms lately is that the complexity of decentralised system is ignored and it is oriented towards only one form of decentralisation (e.g., only decentralisation of money). Consequences of such short-sightedness not only do not allow feeling the advantages of decentralisation, but also may cause such results as deficiency of government and macro-economic instability.

Thus, intergovernmental assessment of fiscal decentralisation may not be performed without analysing institutional and political situation of the State first, i.e.: historical development of the object, influence of the change of political organisations to administrative territorial division of the country, self-governance guidelines indicated in the Constitution of that country and its legislation, as well as their actual implementation and assessment of the self-governance elections' system.

\section{References}

1. ADDCN. (2007). State Restructuring and Issues of Local Self Governance in Nepal. Internet access: http://www.addcn.org.np/quick_file/ State\%20Restructuring\%20and\%20Issues $\% 20$ of $\% 20$ Local $\% 20$ Self $\% 20$ Governance $\% 20 \mathrm{in} \% 20$ Nepal1.pdf.

2. Bardhan, P. (2002). Decentralization of Governance and Development // Journal of Economic Perspectives. Vol. 16, No. 4, pp. 185205. doi: 10.1257/089533002320951037.

3. Bird, R., Ebel R. (2007). Fiscal Fragmentation in Decentralized Countries. - Cheltenham: Edward Elgar.
4. Bosch, N., Duran, J. (2008). Fiscal Federalism and Political Decentralisation. - Cheltenham: Edward Elgar.

5. Brette, O. (2003). Thorstein Veblen's Theory of Institutional Change: Beyond Technological Determinism // European Journal of the History of Economic Thought, Vol. 10, No. 3, pp. 455477. doi: 10.1080/0967256032000106698.

6. Cheema, G. S., Rondinelli, D. (2007). From Government Decentralisation to Decentralised Governance / In Decentralising Governance: Emerging Concept and Practices ed. G. S. Cheema and D. Rondinelli. - Washington: Brookings Institution, pp. 1-20. 
7. Dafflon, B., Madies, T. (2009). Décentralisation: quelques principes issus de la théorie du fédéralisme financier. [Decentralization: A Few Principles from the Theory of Fiscal Federalism.] Notes and documents 42. - Paris: Agence Française de Développement.

8. Devas, N. (2008). Decentralisation and the Implications for Local Government Finance / In Devas, N., Alam, M., Delay, S., Koranteng, RO and Venkatachalam, P., Financing Local Government, Commonwealth Secretariat. London, pp. 11-23.

9. Dorfman, J. (1934). Thorstein Veblen and His America. - Cambridge: Belknap Press of Harvard University Press.

10. EbelR. D., Yilmaz, S. (2002). On the measurement and impact of fiscal decentralization // Policy Research Working Paper Series. No. 2809. Washington D.C.: World Bank.

11. European Charter of Self-Government (1985). Strasbourg: Council of Europe. Internet access: https://www.coe.int/en/web/conventions/ full-list/-/conventions/treaty/122

12. Fleiner, T. (2000). Federalism: Basic Structure and Value of Switzerland Recent Developments In Swiss Federalism. Internet access: http:// www.thomasfleiner.ch/files/categories/ IntensivkursII/Switzerland.pdf

13. Frank, J. (1986). The New Keynesian Economics: Unemployment, Search, and Contracting. Bringhton: Wheatsheaf.

14. Hamilton, W. H. (1919). The Institutional Approach to Economic Theory // The American Economic Review. Vol. 9, No. 1, pp. 309-318.

15. Israel, A. (1992). Issues for Infrastructure Management in 1990s. Wold Bank Discussion Paper 171. Washington, D. C.

16. Martinez-Vazques, J. (2008). Revenue Assignments in the Practice of Fiscal Decentralisation / In Fiscal Federalism and Political Decentralisation, ed. N. Bosch and J. Duran. - Cheltenham: Edward Elgar.

17. Martišius, S. (2005). Ekonominių teorijų raida 1870-1970 metais // Pinigų studijos. Ekonomikos teorija ir praktika. Nr. 2, pp. 47-57.

18. Maskin, E., Qian, Y., Xu, C. (2000). Incentives, Information, and Organizational Form // Review of Economic Studies. Vol. 67, No. 2, pp. 359-378. doi: 10.1111/1467-937X.00135

19. Oates, W.E. (1972) Fiscal Federalism. New York: Harcourt Brace Jovanovich.
20. Osei-Kufuor, P., Bakare I., A., O. (2013). Conceptualizing Institutionalised Decentralisation: Implications for Competing Theories in Development. International // Journal of Humanities and Social Science Invention. Vol. 2, No. 9, pp. 32-45.

21. Qian, Y., Roland, G. (1998). Federalism and the Soft Budget Constraint // American Economic Review. Vol. 88, No. 5, pp. 1143-1162. doi: 10.2139/ssrn. 149988

22. Ribot, J. C. (2004). Waiting for Democracy: The Politics of Choice in Natural Resource Decentralisation. - Washington D.C.: World Resources Institute.

23. Seabright, P. (1996). Accountability and Decentralization in Government: An Incomplete Contract Model // European Economic Review. Vol. 40, No. 1, pp. 61-89. doi: 10.1016/0014-2921(95)00055-0.

24. Smoke, P. (2003). Decentralisation in Africa: Goals, Dimensions, Myths and Challenges // Public Administration and Development. Vol. 23, No. 1, pp. 7-16. doi: 10.1002/pad.255.

25. Sonin, K. (2003). Provincial Protectionism, CEFIR Mimeo. doi: 10.2139/ssrn.403960

26. Tanzi, V. (1996). Fiscal Federalism and Decentralization: A Review of some Efficiency and Macroeconomic Aspects. - Annual World Bank Conference on Development Economics, 1995. Washington, DC: World Bank, pp. 295-316.

27. Tanzi, V. (2000a). Fiscal Federalism and Decentralisation: A Review of Some Efficiency and Macroeconomic Aspects / In Policies, Institutions and the Dark Side of Economics, ed. V. Tanzi. - Cheltenham: Edward Elgar.

28. Tanzi, V. (2000b). On Fiscal Federalism: Issues to Worry About. Internet access: http://www. imf.org/external/pubs/ft/seminar/2000/fiscal/ tanzi.pdf.

29. Tiebout, C. (1956). A Pure Theory of Local Expenditures // Journal of Political Economy. Vol. 64, No. 5, pp. 416-424. doi: 10.1086/257839.

30. Persson, T., Tabellini, G. (2000). Political Economics: Explaining Economic Policy. Cambridge, MA: MIT Press.

31. World Bank. (1990). Strengthening Local governments in Sub-Sacharan frica. E.D.I. Policy Seminar report. 21. - Washington D.C.: World Bank.

The paper submitted: October 5, 2018 Prepared for publication: December 10, 2018 


\section{Gerda ŽIGIENĖ \\ DECENTRALIZACIJOS PRIELAIDOS INSTITUCINĖS IR POLITINĖS EKONOMIKOS KONTEKSTE}

\section{S a n t r a u k a}

Šiuolaikinejje politikoje ir ekonominèje literatūroje neabejojama, kad decentralizacija padeda užtikrinti viešojo valdymo efektyvumą, skaidrumą, piliečių dalyvavimą valdyme ir vietos valdžios atsakomybę prieš piliečius. Net turint galvoje pakankamai gausią literatūrą decentralizacijos tema, dažniausiai koncentruojantis i pačias reformas, fiskalinę decentralizaciją, tarpvyriausybinius fiskalinius santykius, neretai neatkreipiamas demesys ị ne visuomet adekvačiai vartojamą kontekstą ir sąvoką. Taigi, kyla klausimu, ar decentralizacijos sąvoka yra tokia aiš$\mathrm{ki}$, suprantama ir vienodai interpretuojama istoriniame, socialiniame, politiniame ir ekonominiame kontekste.

Straipsnyje aptariami daugiabriauniai decentralizacijos aspektai, vertinant šio reiškinio kompleksiškumą ir daugiareikšmiškumą skirtingais laikotarpiais ir skirtingos ekonomikos bei politinès sandaros šalyse. Decentralizacijos sąvoka dažnai vartojama neịvertinant jos skirtingų aspektų atskirose dimensijose. Kai sąvoka yra niveliuojama, tuomet jos reikšme neretai iškreipiama. $\mathrm{O}$ vardija$\mathrm{mi}$ ar taikomi trūkumai bei privalumai neatspindi aktualios situacijos. Todèl norint ivvertinti decentralizacijos (ar ji būtu politine, ar administracinè, ar fiskalinè) lygi šalyje, pirmiausia reikia suvokti jos politinę-institucinę prigimtị. Todèl šio straipsnio tikslas - apžvelgti decentralizacijos sąvokos raidos kontekstą instituciniu aspektu bei darant takoskyrą tarp decentralizacijos ir federalizmo. Tik aiškiai apibrèžus decentralizacijos sąvoką institucinès ir politinès ekonomikos kontekste, galima taikyti jos prielaidas, naudotis privalumais ir ieškoti būdų, kaip kompensuoti trūkumus, nes neadekvati konceptualizacija, ignoruojanti specifinị šalies kontekstą, arba priverstinis procesų taikymas užkerta kelią optimaliam praktiniam decentralizacijos igyvendinimui.

Straipsnyje aptariamas decentralizacijos sąvokos prasmès kitimas laike, institucinè ekonomika ir politinès valstybių santvarkos bei decentralizacijos lygmuo tų politinių santvarkų kontekste; analizuo- jami skirtumai tarp unitarinių ir federalinių valstybių, paraleliai brežiant skirtumus tarp decentralizacijos ir federalizmo sąvokų bei jų reikšmių, taip pat ir pačių procesų valdymo.

Literatūros šaltiniuose decentralizacijos ar fiskalinio federalizmo tema daroma tipiška prielaida, kad žemesni valdymo lygmenys surenka mokesčius ir išleidžia biudžeto pinigus. Tačiau šis vietos valdžios léšų surinkimo ir išleidimo aspektas dar neparodo, kokias konkrečiai galias ir ịtaką vietos valdžia turi minètų lèšų administravimui. Kitaip tariant, koks konkrečioje valstybejje yra decentralizacijos lygmuo. Norint tą lygmeni nustatyti, decentralizaciją reikia nagrinèti nevienareikšmiškai, nes tai daugiabriaunis reiškinys. Yra šalių, kuriose kalbama apie decentralizaciją, nors tuo metu vietos valdžia tik perskirsto surinktus mokesčius centriniame valdymo lygmenyje, tačiau yra šalių, kur vietos valdžia pakankamai autonomiškai tvarkosi, remdamasi savo administracinemis institucijomis. Abiem atvejais kalbama apie decentralizaciją.

Tad prieš nagrinèjant konkrečią situaciją konkrečioje šalyje turi būti aiškiai atskleistas sąvokos daugiabriauniškumas.

Pagrindinè kai kurių šalių, pastaruoju metu vykdančių decentralizacijos reformas, problema yra ta, kad ignoruojamas decentralizuotos sistemos kompleksiškumas ir orientuojamasi tik ị vieną decentralizacijos formą (pvz., tik pajamų decentralizaciją). Tokio trumparegiškumo padariniai ne tik neleidžia pajusti decentralizacijos privalumo, bet gali lemti tokius rezultatus kaip valdžios deficitas ir makroekonominis nestabilumas.

Taigi tarpvyriausybinis fiskalinès decentralizacijos vertinimas negali būti atliekamas prieš tai neišnagrinëjus institucinès ir politinès valstybès situacijos, t. y. istorinés objekto raidos, politinių santvarku pasikeitimo itakos administraciniam teritoriniam šalies suskirstymui, būtent tos šalies konstitucijoje ir teisès aktuose nurodytų savivaldos gairių ir jų realaus iggyvendinimo, savivaldos rinkimų sistemos vertinimo. 